\title{
The Effectiveness of Using Thematic Dominoes Technique toward Student's Vocabulary at Second Grader of SMPN 3 Kerinci
}

\author{
Efa Silfia ${ }^{1}$ \\ ${ }^{1}$ Program Studi Bahasa Inggris, FKIP Universitas Batanghari \\ Correspondence Email: efa.silfia@unbari.ac.id
}

\begin{abstract}
Abstrak. Penelitian ini bertujuan untuk menemukan adakah pengaruh penggunaan teknik Thematic Dominoes terhadap penguasaan kosa kata siswa kelas dua SMPN 3 Kerinci. Penguasaan kosa kata dengan benar sangat penting dalam pembelajaran bahasa Inggris, karena ini akan membantu siswa untuk mudah menguasai kemampuan membaca, berbicara, mendengar dan menulis. Dalam penelitian ini, peneliti menggunakan metode experiment yang mana dengan melakukan tes awal, tindakan dan tes akhir. Dalam pemilihan sampel, peneliti menggunakan teknik sampel nonprobability. Peneliti menggunakan koin lalu dilemparkan untuk memilih kelas eksperimen dan kelas control yaitu kelas VIII A sebagai kelas control dan kelas VIII B sebagai kelas eksperimen. Instrumen penelitian ini adalah tes kosa kata, dengan menggunakan tes pilihan ganda. Jumlah soal pada test yaitu 50 soal. Untuk menemukan hasil hipotesis penelitian, peneliti menggunakan rumus $t$ - tes yang mana skornya adalah 2. 19 dan skor $t$ tabel nya adalah 1.6918. Hipotesis dapat diterima sebagaimana hasil dari $t$ - tes lebih besar dari $t-$ table. Peneliti menyimpulkan bahwa teknik Thematic Dominoes mempengaruhi penguasaan kosa kata siswa pada kelas VIII di SMPN 3 Kerinci.
\end{abstract}

Kata kunci: teknik Thematic Dominoes; kosa kata

\section{INTRODUCTION}

Vocabulary is the set of words known by the person or entity, and is part of a particular language. It is defined as the set of all the words are understood by the person orally, and the words are used by person to make a new sentence. In some literature, it can be found the meaning of vocabulary. There are some definitions of vocabulary. Linse ( $2005: 121$ ) states that vocabulary is the collection of words that an individual knows. Moreover, it is one of the four language components, which are spelling, grammar, phonology and vocabulary (Nugroho: 2007). It is an important element that cannot be separated from each other in language learning process.

From the definition, it is important to realize that the vocabulary is owned by learners should be developed. Although vocabulary is the one that is emphasized, it does not mean other kinds of language components-grammar and pronunciation-are less important. All of these aspects are learned together, because they are attached one to another. Vocabulary is extremely large and also varies. Nobody ever learns all the words in any language, but they can enlarge the number of words they have. The larger vocabulary the students have, it can help them in many ways; students' reading ability and writing ability will improve as they learn new words, and the more words they know the better their chance will be to do well on the vocabulary questions, in the school. Therefore, it is highly essential for English teacher to help their students in mastering vocabulary along with grammar and pronunciation.

Furthermore, vocabulary has significant role in communicating process. The communication will succeed or not it depends on the accurate vocabulary understanding. Students cannot master intensively in listening, speaking, reading and writing skill if they do not know the vocabulary well.

Based on observation and informal interview, researcher with English teacher SMPN 3 Kerinci. The researcher found that the students had low score in final test, they were mostly coming from the second year students. In Junior High School, the researcher found some problem of students' ability in vocabulary. In fact, the students had very poor in mastering English vocabulary. Based on the information gotten from the teacher, the teaching learning process did not work properly, because it is very hard to make students active when teaching learning process took place.

From these problems above, students are required to master the vocabulary being used. Instructional media can help to improve English language skills, included to help students in mastering the English vocabulary. Some techniques on teaching vocabulary can be used to explain the meaning of words, and every teacher has to determine the best technique to teach the meaning of words. The teacher needs to consider whether the technique is able to improve student's retention.

One of the commonly used media in increasing mastery of English vocabulary is a game. Games can make learning a fun atmosphere. In the even to fun learning atmosphere for students, it is easy to capture the lessons given. A thematic domino is one of games that can be made to enrich the mastery of English vocabulary.

Thematic Dominoes is a game of dominoes that have a theme. The game comes from lessons learned in accordance with English. For example, the theme of the Profession, the vocabulary is related to the profession. Thematic Dominoes can be played in groups. Just like a game of dominoes, it's just the Thematic Dominoes students search for answering based on the question mark. Thematic Dominoes game requires students to actively compete a winner in the game. Students can actually increase the vocabulary they have. If students are rich in vocabulary, it is easier for them to improve their English vocabulary (Utaminingsih, 2010:1).

According Nurhikmah (2010 : 30), Dominoes game is a method of learning which refers to how to play dominoes at large. There are several advantages of Thematic Dominoes game. These games can make learning fun and different and the vocabulary is related in 
the material easy to memorize. It can also make students critical thinking, remembering, predicting, and guess the meaning of words. This activity makes the students to be actively in participating and training them to speak English when they try to read the questions contained in dominoes. This game also encourages students to listen to the questions carefully. At higher levels, the question in this game should be tailored to the student's ability level.

Moreover, Paul Ginnisin Utaminingsih (2010: 8) explains that Thematic Dominoes can be used in a preactivity, while-activity and post-activity. In the preactivity, Thematic Dominoes is used to determine how much preparation students when they will begin the process of learning. In the while-activity, Thematic Dominoes game can be given to consolidate the basic ideas and assess the diagnostic study at the time. And in post-activity, this game can be ideal to revise the topic.

Based on the background above, the writer would like to do a research about the effect of using thematic dominoes technique on students' vocabulary at second year students of Junior High School.

\section{RESEARCH METHOD}

This research was experimental research. An experiment is scientific investigation in which the researcher manipulates one or more independents variables, controls any other relevant variables, and observes the effect of manipulations on the dependent variable. This study was used quasi-experimental design. According Sukmadinata (2011 : 59), "Quasiexperimental basically the same as a pure experiment, the difference is in the control variable." It control only performed one variable which is variable in view of the most dominant. While Donald Ary (1989: 265) says that Quasi-experimental designs are similar to be randomized experimental designs in that they involve manipulation of an independent variable but differ in that subjects are not randomly assigned to treatment groups. So, in this research, the population was all of the eight grade students of SMP N 3 Kerinci. The number of the population is 36 students. There were two classes of the eight grade students at SMPN 3 Kerinci. The sample of this research was 17 students of VIII A and 19 students of VIII B. Because of the population is too small so the researchers took all of the population as the sample in this study. The researcher uses nonprobability sampling technique, It is sampling jenuh. According Sugiono (2009 : 124), sampling jenuh is sampling technique when all members of the population are used as samples.

The data of this research was quantitative data. It is students' score in mastering vocabulary. To obtain the data, researcher gave the pre-test and post-test to all class. The instrument of the research was vocabulary test. The questions were 50 given to the students and used multiple choice. To know the validity of test, the researcher took place try out test in content validity. Content validity can be done by compare the content with material teached. The test was designed to fulfill the need to investigate students' vocabulary ability. To achieve this validity, the content of the test was taken from the English book and internet sources. Besides, the test was consulted with the researcher advisor and teacher.

The result of the try out test was tested by using Kuder-Richardson Formula 21. (Sugiyono, 2009: 186).

$\mathrm{r}_{1}=\left(\frac{k}{k-1}\right)\left(1-\frac{M(k-M}{k(S D)^{2}}\right)$ formula:

The mean (M) score was obtained by using

$\mathrm{M}=\frac{\sum X}{N}$

Then, the standard deviation was also calculated by using formula:

$\mathrm{SD}=\sqrt{\frac{\sum x 2-\left[\frac{\left(\sum x\right) 2}{n}\right]}{n-1}}$

Legends:

$r_{1}=$ the reliability of the instrument

$\mathrm{k}=$ the number of the items in the test

$\mathrm{M} \quad=$ the mean of the scores

$\mathrm{X}=$ the score

$\mathrm{N} \quad=$ the number of students

$\mathrm{SD} \quad=$ the standard deviation of the score

The test was called reliable if the value of $r$ is more than 0, 09 (Gay, 1992).

The data of pre-test and post-test score was analyzed and interpreted based on the scoring interpretation of students' achievement. The researcher also was used t-test.

The formula of t-test was as follow:

$$
\begin{aligned}
& t=\frac{x_{1}-x_{2}}{\sqrt{\left(\frac{s s_{1}+s s_{2}}{n_{1}+n_{2}-2}\right)\left(\frac{1}{n_{1}}+\frac{1}{n_{2}}\right)}} \\
& x_{1=\frac{\sum x_{1}}{n_{1}}} \\
& x_{2=\frac{\sum x_{2}}{n_{2}}} \\
& s s_{1}=\sum x_{1}^{2}-\left(\frac{\sum x_{1}}{n_{1}}\right) 2 \\
& s s_{2}=\sum x_{2}^{2}-\left(\frac{\sum x_{2}}{n_{2}}\right) 2
\end{aligned}
$$

In which

$t \quad$ : The value of $t$-calculated

$\mathrm{x}_{1} \quad$ : The mean of the experimental group

$x_{2} \quad$ : The mean of the control group

$\mathrm{ss}_{1} \quad$ : The variance of the experimental group

$\mathrm{ss}_{2} \quad:$ The variance of the control group

$\mathrm{n}_{1} \quad$ : The number of sample in experimental group

$\mathrm{n}_{2} \quad$ : The number of sample in control group

\section{FINDINGS AND DISCUSSION}

To know the reliability of the test, the researcher used the formula of Kuder Richardson 21 (KR-21). This test was given to the one class of eight grade students. It was class VIII A. Based on the calculation of this formula, it was found that the frequency of reliability of the test is 1.07 . It could be concluded that the test was reliable for standard achievement test which frequency 
was over 0.90. The pre-test was held one day. This research was conducted about sixth meetings. There were four meetings for teaching and two meetings for pre-test and post-test. The English subject is taught three a week. Then, the post-test was given for both classes. The schedule of conducting this research is in table below.

Table 1. The Schedule in Conducting the Research

\begin{tabular}{cccc}
\hline No & Meeting & Theme & Date \\
\hline 1 & Pre-test & All Theme & October $8^{\text {th } 2012}$ \\
2 & Meeting 1 & Things in the school 1 & October $10^{\text {th } 2012}$ \\
3 & Meeting 2 & Things in the school 2 & October $12^{\text {th } 2012}$ \\
4 & Meeting 3 & Pofession 1 & October $15^{\text {th } 2012}$ \\
5 & Meeting 4 & Profession 2 & October $16^{\text {th } 2012}$ \\
6 & Post-test & All Theme & October 19 \\
\hline
\end{tabular}

\section{The Result of Pre - Test and Post Test in Experiment Class}

In experimental group, there were 19 students' score taken from the pre and post-test data. The mean of pre-test score in experimental class was 56.5 which the lowest score was 30 and the highest score was 94 . Thematic dominoes technique was given as treatment for this class. The treatment was given for four meetings. After that, the researcher gave the post-test for this class. The post-test result for this class shown that the mean score of this class was 84.10 with the lowest score was 70 and the highest score was 100 . The result of pretest and post-test for experimental class could be interpreted based on the score interpretation for students' achievement. Table shows the distribution of pre-test and post-test score of students in Experimental class as follow:

Table 2. The Distributions of Pre-test and Post-test Score in Experimental Class

\begin{tabular}{|c|c|c|c|c|c|}
\hline \multirow{2}{*}{ Score } & \multirow{2}{*}{ Category } & \multicolumn{2}{|c|}{ Pre-test } & \multicolumn{2}{|c|}{ Post-test } \\
\hline & & Frequency & Percentage & Frequency & Percentage \\
\hline $81-100$ & Very Good & 1 & $5.26 \%$ & 10 & $52.63 \%$ \\
\hline $61-80$ & Good & 5 & $26.31 \%$ & 9 & $47.37 \%$ \\
\hline $41-60$ & Fair & 11 & $57.89 \%$ & - & - \\
\hline $21-40$ & Weak & 3 & $15.78 \%$ & - & - \\
\hline $0-20$ & Poor & - & - & - & - \\
\hline \multicolumn{2}{|c|}{ Total } & 19 & $100 \%$ & 19 & $100 \%$ \\
\hline
\end{tabular}

From the table above, the pre-test scores in experimental class showed that the students' distributions were not distributed for all categories. The most students' distributions were in good category (5 students). It was only 1 student who was able to obtain very good category.

For the post-test scores in experimental class, it showed the students' distribution was not distributed for all categories. The students' distribution got the significant effect or improvement which the most students' distributions were in fair category. Besides, the students' distributions for very good category increase 9 points from students' pre-test distribution. Students got weak category was decreased 0 point. Then, there were none student in poor category.

\section{The Result of Pre- Test and Post-Test in Control Class}

There were 17 students in control class. The pretest result in control group showed that the mean score of pre-test result was 71.2. From the result of pre-test, the lower score was 10 and the highest score was 96.

Before the post-test, the students in control class were given the Vocabulary Method treatment. This treatment was given for four meeting. After that, the post-test was administered in this class. The data shows the mean score of post-test result was 73.88. The lowest score was 40 and the highest score was 96 . The distributions of pre-test and post-test score in control group were as follows:

Table 3. The Distribution of Pre-test and Post-test Score in Control Group

\begin{tabular}{|c|c|c|c|c|c|}
\hline \multirow{2}{*}{ Score } & \multirow{2}{*}{ Category } & \multicolumn{2}{|c|}{ Pre-test } & \multicolumn{2}{|c|}{ Post-test } \\
\hline & & Frequency & Percentage & Frequency & Percentage \\
\hline $81-100$ & Very Good & 6 & $35.29 \%$ & 5 & $41.17 \%$ \\
\hline $61-80$ & Good & 7 & $41.17 \%$ & 8 & $47.05 \%$ \\
\hline $41-60$ & Fair & 2 & $11.76 \%$ & 3 & $17.66 \%$ \\
\hline $21-40$ & Weak & 1 & $5.88 \%$ & 1 & $5.88 \%$ \\
\hline $0-20$ & Poor & 1 & $5.88 \%$ & - & - \\
\hline \multicolumn{2}{|c|}{ Total } & 17 & $100 \%$ & 17 & $100 \%$ \\
\hline
\end{tabular}

From the table above, the pre-test scores in control class showed that the students' distributions were not distributed for all categories. The most students' distributions were in good category (7 students). There were only 6 students who were able to obtain very good category.
For the post-test scores in control class, it showed that the students' distribution was not distributed for all categories. But the students in very good category decrease from 5 students to 1 student. Then, there were none student in poor category. 


\section{Data Analysis}

The t-test formula was applied to know whether there was a significant difference between post-test score of both experimental class and control class.

Based on the calculation of t-test, it was found that the value of t-test was 2.19 . The value of t-table was 1.6918 with the degree of freedom was 34 and the level of confidence 0.05 . So, it concluded that the value of $t$ test was higher than value of $t$-table.

\section{Hypotheses Testing}

From the data analysis, the hypotheses can be tested as follow:

Null hypothesis $\left(\mathrm{H}_{0}\right)$ is accepted:

"The value of t-test was less than the value of t-table" Alternate Hypothesis $\left(\mathrm{H}_{1}\right)$ is accepted:

"The value of $t$-test was higher than the value of $t$ table"

On the basis of calculation, the t-value of level significance 0.05 with $\mathrm{df}=34(\mathrm{n} 1+\mathrm{n} 2-2)$ was 1.6918 . The post-test result was tested by using t-test formula and the calculation of t-test was 2.19. So, it can be seen that the value of t-test was higher than the value of $t$ table. It meant that the Alternate hypothesis was accepted. So, it can be concluded that there was significant effect of using thematic dominoes technique on the student's vocabulary.

Based on the result of the pre-test, it was obtained avarage grade classroom experiment and control were both not getting treatment for a class experiment were 56.5 and 71.2 for the control class. Then after conducting the treatment technique using thematic dominoes, the experimental class learning game using the matic dominoes technique scoring avarage of 84.1 , while the control class used conventional methods to obtain the value of 73.8 .

To find the result of the research hypothesis, the researcher uses a formula which t-test score is 2.19 and the score of the t-table is 1.6918 . Hypothesis can be accepted as a result of the t-test greathe $(>)$ from the $t-$ table. Based on the analysis of research result, it is found that there is significant and better effect for students' vocabulary score between two classes or group who were taught by using thematic dominoes technique and those who were not. It can be seen between the differences of the pre-test results before treatment with the result of post-test after treatment in both of groups.

Thus, the conclusion that can be taken English vocabulary learning methods premises thematic dominoes game more efective technique compared with conventional methods. While the weakness of the method the game is, the less time in playing the game, not enought to just play once, have repeatedly and become crowded classroom conditions.

Thematic dominoes technique could improve students' vocabulary. The students were more motivated when they learned English by using thematic dominoes technque. They participated in English class more happily, more interested and more focused. They focused to write and mention vocabulary and thematic dominoes technique helped them to understand the vocabulary. So, adter the author analyzed all of the data. The author concluded that the Thematic Doinoes Technique has an influence on students' vocabulary in class VIII SMP N 3 Kerinci.

\section{CONCLUSION}

After conducting the research, there are two conclusions that researcher got for this research. The first, the result of mean's difference analysis in experimental class was higher than the mean's difference of control class.

The second, based on the calculation of t-test formula, it was found that the value of t-test (2.19) was higher than t-table (1.6918), it indicated that there were significant difference effect on student's vocabulary that taught by using thematic dominoes technique. It meant that the hypothesis of this study was there was any significance effects of using thematic dominoes technique on student's vocabulary at the second year of SMP N 3 Kerinci was accepted.

It was suggested for English teachers at Junior High School, especially English teachers of SMPN 3 Kerinci to consider thematic dominoes technique as one of way to increase students' vocabulary. Then, the English teachers should be creative in explaining the learning material in order to stimulate the students' interest, motivation to increase their English vocabulary.

\section{REFERENCE}

Ary, Donald. 1989. Introduction to Research in Education. Canada. Nelson Education, Ltd.

Creswell, W. Jhon. 2012. Educational research: Planning, Conducting, and Evaluating Quantitative and Qualitative Research. Boston. University of Nebraska-Lincoln.

Gay. 1992. Educational Research. Macmilan Publishing Company.

http://id.wikipedia.org/wiki/Kosakata. accessed in (may $\underline{05}, 2012$ ).

http://duniabaca.com . Teaching Vocabulary (2008). Accssed in (may 08, 2012).

Jones, P. Watcyn. 1993. Vocabulary Games and Activities for Teachers. Penguin Books.

Linse, T. Caroline. 2005. Practical English Language Teaching: Young Learners.America.New York.

Nurhikmah. 2010. Efektivitas Metode Permainan Domino Dalam Peningkatan Hafalan Kosakata Bahasa Jepang (eksperimen terhadap siswa kelas X SMA Laboratorium Percontohan UPI Tahun Ajaran 2009-2010). Bandung.

Sukmadinata, N. Syaodih. 2011. Metode Penelitian Pendidikan. Bandung. Remaja Rosdakarya.

Sugiyono. 2009. Metode Penelitian Pendidikan. Bandung. Alfabeta.

Utaminingsih, Yayuk. 2010. Permainan Dominoes Sebagai Media Pembelajaran Penguasaan kosakata Bahasa Inggris. Makalah. Jambi : Program Pasca Sarjana Tekonologi Pendidikan Universitas Jambi.

Yantias. 2009. Pengembangan Strategi Domino Dalam Pembelajaran Menulis Cerpen Siswa Kelas $X$ SMA Islam Malang Tahun Ajaran 2008-2009. Skripsi. Malang : Universitas Negri Malang. 
Yunita. 2008. Pengembangan Permainan Domino sebagai Media Pembelajaran Kosakata dan Tata Bahasa Jerman di SMA Negeri 7 Malang. skripsi. Malang : Fakultas Sastra Jerman UM. 